\title{
Effects of seasonal changes in feeding management under part-time grazing on the evolution of the composition and coagulation properties of raw milk from ewes
}

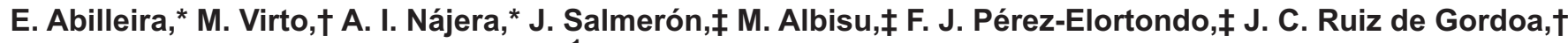 \\ M. de Renobales, $†$ and L. J. R. Barron*1 \\ *Tecnología de Alimentos, \\ †Bioquímica y Biología Molecular, and \\ ‡Nutrición y Bromatología, Facultad de Farmacia, Universidad del País Vasco/Euskal Herriko Unibertsitatea, Paseo de la Universidad 7, \\ 01006 Vitoria-Gasteiz, Spain
}

\section{ABSTRACT}

Ewe raw milk composition, rennet coagulation parameters, and curd texture were monitored throughout the milk production season in 11 commercial flocks reared under a part-time grazing system. Milking season lasted from February to July. During that period, the diet of the animals shifted from indoor feeding, consisting of concentrate and forage, to an outdoor grazing diet. Lean dry matter, fat, protein, calcium, and magnesium contents increased throughout the milking season, as did rennet coagulation time, curd firmness, and curd resistance to compression. However, lean dry matter, protein content, and curd resistance to compression stabilized when sheep started to graze. Principal component analysis correlated curd resistance to compression and proteins, whereas curd firmness was highly correlated with fat content and minerals. Discriminant analysis distributed milk samples according to the feeding management. Curd firmness, fat, and magnesium turned out to be discriminant variables. Those variables reflected the evolution of the composition and coagulation parameters when fresh pasture prevailed over other feeds in the diet of the flocks. The present study shows that seasonal changes associated with feeding management influence milk technological quality and that milk of good processing quality can be obtained under part-time grazing.

Key words: feeding, coagulation property, milk composition, ewe raw milk

\section{INTRODUCTION}

Throughout the world, ewe milk is mainly used for cheesemaking. Hence, the capability of sheep milk to be transformed into high-quality cheese is a major concern among cheesemakers, in particular when they use

Received December 9, 2009.

Accepted May 19, 2010.

${ }^{1}$ Corresponding author: luisjavier.rbarron@ehu.es raw milk (Bencini, 2002). Coagulation properties have been widely used by researchers to assess the processing performance of milk because it is easier than making cheese batches and measuring cheese yield (Bencini, 2002). Renneting parameters of milk are affected by physicochemical properties, such as $\mathrm{pH}$, casein micelle structure, and mineral content (Nájera et al., 2003; Park et al., 2007). The physicochemical characteristics of milk are related to its composition, which varies with diet, feeding, season, management, breed, reproduction and sanitary characteristics, and environmental conditions (Morand-Fehr et al., 2007; Park et al., 2007).

Because milk production represents the major cost of cheese production, it is important for manufacturers to obtain milk of high technological and sanitary quality at the lowest price. This is even more important for ovine milk because it is much more expensive than cow milk (Jaeggi et al., 2005). The use of pastures to feed the sheep can help reduce milk production costs without compromising milk production (García-Rodríguez and Oregui, 2004). Taking advantage of natural resources is cheaper than purchasing concentrate formulations in the market. Hence, pasture grazing contributes to the sustainability of the whole system, but it is critical to know how it affects milk processing quality. In most countries sheep milk production is seasonal and flock diet often changes throughout lactation because of seasonal forage and changing nutritional requirements of the animals. Because of climatologic conditions it is not always possible to take advantage of natural resources, and grazing periods are usually limited to spring and early summer months. Hence, the effects of stage of lactation are confounded with those of season and diet and cannot be dealt with separately in commercial flocks (Walker et al., 2004).

Seasonal differences in the composition of bulk raw milk from several Latxa flocks at different lactation stages have been reviewed (Barron et al., 2001) and technological quality of ewe milk from early- and late- 
Table 1. Production characteristics, milk hygienic quality, and diet composition (average values \pm SD) for the commercial flocks $(\mathrm{n}=11)$ throughout the milk production season

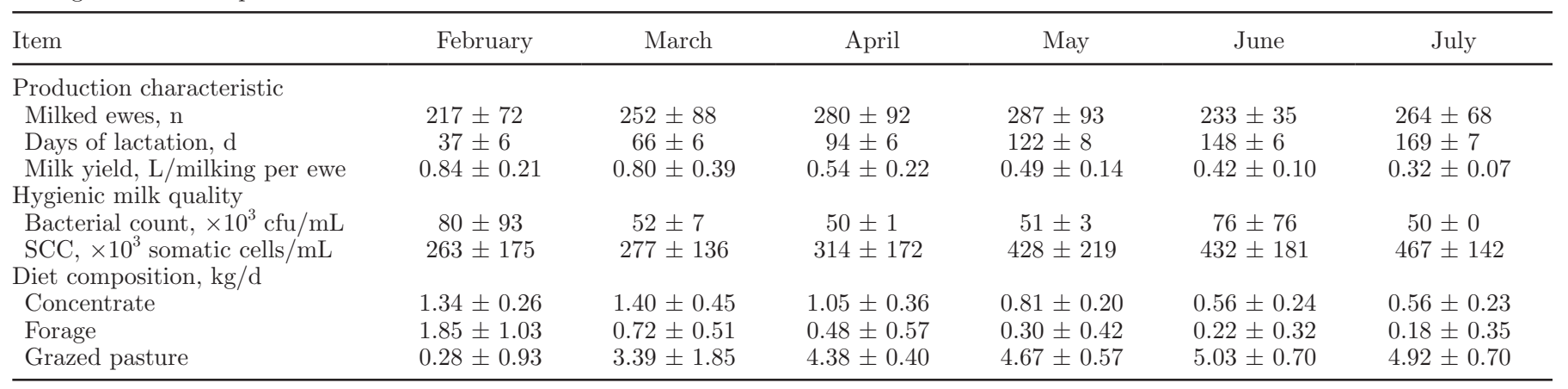

lactation flocks under part-time grazing has been compared (Nájera et al., 2009). Seasonal changes, associated with feeding pattern changes, in ewe milk composition, milk quality, and cheese yield have been also reported (Jaeggi et al., 2005; Morand-Fehr et al., 2007; Park et al., 2007). However, in most of those studies, samples were obtained at only 2 or 3 stages of the milking season and more comprehensive information about the evolution of milk processing performance of individual flocks is still lacking.

The aim of this study was to monitor the evolution of the composition and renneting properties of ewe raw milk throughout the milking season as affected by seasonal changes in feeding under part-time grazing of commercial flocks. Seasonal changes observed in fatty acid composition of milks from those commercial flocks are pending publication.

\section{MATERIALS AND METHODS}

\section{Commercial Flocks and Milk Samples}

Eleven commercial flocks of Latxa ewes were selected. All the flocks belonged to the Protected Denomination of Origin of Idiazabal Cheese and were reared in the Basque Country in northern Spain. Flock size ranged from 200 to 400 ewes because the factories were small and usually run by a single family. Flock management was similar among the 11 farms. Flocks lambed in winter and suckling lambs were weaned at 30 to $45 \mathrm{~d}$. Ewes were milked twice daily using automated milking machines. Sample collection was done in 2006, starting in February and ending in July. Each month, 1.5 L of bulk raw milk was taken from each farmhouse and stored at $4^{\circ} \mathrm{C}$ until analysis within the next $48 \mathrm{~h}$. Flock productive characteristics during the milking season are summarized in Table 1.

\section{Feeding Management}

Sheepherders were interviewed each sampling day to gather information about the fodder composition and diet of the flocks. Feeding management consisted of an indoor period in winter and part-time grazing system in spring and summer. In February, diets were based on concentrate and conserved forages and sheep stayed indoors all day. In March, the grazing season began because good-quality pasture was available. However, large variability in the pasture allowances and levels of supplementation was observed because the transition from indoor feeding to part-time grazing differed slightly from one farm to another. From April, fresh grass prevailed over other feeds in the diet of all the flocks and indoor supplementation decreased progressively as lactation progressed. Table 1 shows average diet composition of the flocks during the milking season. Animals from 7 farms grazed on cultivated private grasslands where ryegrass (Lolium perenne) and white clover (Trifolium repens) were predominant species, whereas animals from 4 farms grazed in noncultivated, community-owned grasslands. The pasture composition of such community-owned grasslands in this area has been reported by Mandaluniz et al. (2009) and consisted of herbaceous species such as Trifolium repens, Festuca rubra, and Agrostis capillaris but also other nongraminoid plants and some shrubs. Fresh pasture intake was estimated from the time spent on pasture and the amount of other feeds ingested (Perojo et al., 2005).

\section{Milk Analysis}

Routine control analyses of milk of each flock were carried out in the Dairy Institute of Lekunberri (Lekunberri, Spain) at 2 -wk intervals. Total milk fat $(\mathrm{g} / 100$ $\mathrm{mL}$ ) was determined following international standard 105 (IDF, 1981) and lean DM (g/100 g) was determined following international standard 021B (IDF, 1987). Somatic cell (somatic cells $/ \mathrm{mL}$ ) and microbiological counts $(\mathrm{cfu} / \mathrm{mL})$ were measured following international standards 148A (IDF, 1995) and 100B (IDF, 1991), respectively. 
Mineral content $(\mathrm{mg} / \mathrm{L})$, total calcium, and total magnesium were measured by atomic absorption as described by De la Fuente et al. (1997) and modified by Nájera et al. (2009) using an AAnalyst 200 atomic absorption spectrometer (Perkin-Elmer, Shelton, CT).

Total nitrogen, noncasein nitrogen $(\mathrm{g} / 100 \mathrm{~mL})$, and NPN $(\mathrm{g} / \mathrm{L})$ were determined following the procedure described by Rowland (1938). Other nitrogen fractions such as casein nitrogen and true protein nitrogen were obtained by difference. Casein and true protein nitrogen fractions were converted into the corresponding protein amount $(\mathrm{g} / 100 \mathrm{~mL})$ by multiplying by 6.38 .

Rennet coagulation parameters were measured using an NT Gelograph (Gel Instrumente AG, Thalwil, Switzerland) as described by Nájera et al. (2003). Milk was coagulated at $32^{\circ} \mathrm{C}$ by adding $3 \mathrm{mg} / 100 \mathrm{~mL}$ of commercial rennet powder (Naturen Plus 1400 NB, CHR Hansen, Madrid, Spain), which consisted of bovine chy$\operatorname{mosin}(80 \% \mathrm{wt} / \mathrm{wt})$ and pepsin $(20 \% \mathrm{wt} / \mathrm{wt})$ with minimum coagulating strength of 1,300 international milk clotting units/g. Rennet coagulation time (min) was the time from the rennet addition to the appearance of the first coagulum. Coagulum and curd firmness were expressed as the inverse of the relative transmission (\% $\mathrm{RET}^{-1}$ ) at the rennet coagulation time and at the cutting time (twice rennet coagulation time), respectively. Milk pH was measured at $20^{\circ} \mathrm{C}$ before each coagulation assay.

Textural measurement of the curds was made using a Texture Analyzer TA-XT2i (Stable Micro Systems, Surrey, UK) equipped with a load cell of $5 \mathrm{~kg}$ and a $\mathrm{P} / 25$ probe as described previously by Nájera et al. (2009). Average force (g) during compression was taken as curd resistance to compression. All the analyses were carried out in duplicate.

\section{Statistical Analyses}

Analysis of variance was used to determine the presence of significant differences $(P \leq 0.05)$ in the analytical variables throughout the production season. A mixed model of repeated measures ANOVA was performed. Flock was used as fixed factor, whereas season was the repeated measures factor. Principal component analysis (PCA) was performed on analytical variables. Only variables with communality values higher than 0.4 were included. The Kaiser criterion (eigenvalue $>1$ ) was used to select the principal components. Factors were rotated (Varimax method) for ease of interpretation. A stepwise discriminant analysis was carried out to classify the samples using the same analytical variables. The SPSS statistical package (version 17.0, SPSS Inc., Chicago, IL) was used for the statistical analyses.

\section{RESULTS AND DISCUSSION}

\section{Milk Composition}

As expected, the effect of season was significant $(P \leq$ $0.05)$ for all compositional variables studied. Flock was also significant $(P \leq 0.05)$ except for the content of fat, magnesium, and milk $\mathrm{pH}$. The interaction term season $\times$ flock was significant $(P \leq 0.05)$ for all the variables except for milk $\mathrm{pH}$.

Total fat content of the milk increased gradually $(P \leq$ $0.05)$ from the beginning to the end of the milk production season (Table 2). As reported previously (Barron et al., 2001; Nájera et al., 2009), total fat content was higher in late-lactation milk than in early-lactation milk. The greatest increase in the fat content occurred from April to May (from 6.10 to $6.92 \mathrm{~g} / 100 \mathrm{~mL} ;+13.44 \%$ ) after a month of outdoor grazing. Milk lean DM was significantly higher $(P \leq 0.05)$ at the end of the season, but the increase happened from March to May (from 10.77 to $10.97 \mathrm{~g} / 100 \mathrm{~g} ;+1.86 \%)$ and then it stabilized (Table 2). The higher solids content of late-lactation milk is, in part, attributed to the concentration effect caused by the decline in milk yield (Sevi et al., 2000), which was quite pronounced from March to April (Table 1). In addition to the effect of lactation stage, the shift to a part-time grazing diet might have contributed to the greatest increase of fat and lean DM contents in the spring months. An experiment conducted in goats demonstrated that milk from animals fed pasture plus concentrate had higher contents of fat, protein, and TS than goats under a confined feeding system without pasture grazing (Soryal et al., 2004).

The content of nitrogen in all milk fractions was higher $(P \leq 0.05)$ at the end of the milking period, except for NPN, which peaked in May and then decreased to lower $(P \leq 0.05)$ levels than in winter (Table 2$)$. Total nitrogen concentration increased until May (from 0.77 to $0.85 \mathrm{~g} / 100 \mathrm{~mL} ;+10.39 \%$ ) and remained constant until the end of the milking season. True protein followed the same pattern, with mean values ranging from 4.65 to $5.19 \mathrm{~g} / 100 \mathrm{~mL}$. Casein content behaved in a similar way, increasing progressively $(P \leq 0.05)$ up to its maximum in May (from 3.92 to $4.40 \mathrm{~g} / 100$ $\mathrm{mL} ;+12.24 \%)$. There was a slight decrease $(P \leq 0.05)$ afterward, but the casein content at the end of the season remained higher $(P \leq 0.05)$ than at the beginning (from 3.92 to $4.31 \mathrm{~g} / 100 \mathrm{~mL}$; +9.95\%). As occurred with total fat, the greatest increase for the true protein and casein fractions was observed from April to May (true protein: from 4.89 to $5.17 \mathrm{~g} / 100 \mathrm{~mL},+5.73 \%$; casein: from 4.10 to $4.40 \mathrm{~g} / 100 \mathrm{~mL},+7.32 \%$ ) after $1 \mathrm{mo}$ of pasture grazing. The concentrations of each nitrogen 
Table 2. Milk compositional variables (average values $\pm \mathrm{SD}$ ) of the commercial flocks $(\mathrm{n}=11)$ throughout the milk production season

\begin{tabular}{|c|c|c|c|c|c|c|}
\hline Item $^{1}$ & February & March & April & May & June & July \\
\hline LDM, g/100 g & $10.77 \pm 0.33^{\mathrm{c}}$ & $10.77 \pm 0.23^{\mathrm{c}}$ & $10.90 \pm 0.17^{\mathrm{b}}$ & $10.97 \pm 0.50^{\mathrm{a}}$ & $11.04 \pm 0.22^{\mathrm{a}}$ & $11.02 \pm 0.25^{\mathrm{a}}$ \\
\hline $\mathrm{TN}, \mathrm{g} / 100 \mathrm{~mL}$ & $0.77 \pm 0.07^{\mathrm{e}}$ & $0.78 \pm 0.03^{\mathrm{d}}$ & $0.81 \pm 0.03^{\mathrm{c}}$ & $0.85 \pm 0.07^{\mathrm{b}}$ & $0.85 \pm 0.05^{\mathrm{ab}}$ & $0.85 \pm 0.04^{\mathrm{a}}$ \\
\hline $\mathrm{NCN}, \mathrm{g} / 100 \mathrm{~mL}$ & $0.15 \pm 0.01^{\mathrm{c}}$ & $0.16 \pm 0.02^{\mathrm{c}}$ & $0.16 \pm 0.02^{\mathrm{b}}$ & $0.16 \pm 0.03^{\mathrm{b}}$ & $0.17 \pm 0.02^{\mathrm{a}}$ & $0.17 \pm 0.01^{\mathrm{a}}$ \\
\hline Protein, g/100 mL & $4.65 \pm 0.46^{\mathrm{d}}$ & $4.76 \pm 0.18^{\mathrm{c}}$ & $4.89 \pm 0.16^{\mathrm{b}}$ & $5.17 \pm 0.46^{\mathrm{a}}$ & $5.19 \pm 0.35^{\mathrm{a}}$ & $5.19 \pm 0.26^{\mathrm{a}}$ \\
\hline Casein, g/100 mL & $3.92 \pm 0.45^{\mathrm{e}}$ & $4.01 \pm 0.18^{\mathrm{d}}$ & $4.10 \pm 0.17^{\mathrm{c}}$ & $4.40 \pm 0.39^{\mathrm{a}}$ & $4.31 \pm 0.28^{\mathrm{b}}$ & $4.31 \pm 0.23^{\mathrm{b}}$ \\
\hline $\mathrm{Ca}, \mathrm{mg} / \mathrm{L}$ & $1,692.75 \pm 98.65^{\mathrm{c}}$ & $1,816.21 \pm 152.76^{\mathrm{b}}$ & $1,850.83 \pm 149.52^{\mathrm{b}}$ & $1,913.37 \pm 196.13^{\mathrm{a}}$ & $1,971.08 \pm 238.94^{\mathrm{a}}$ & $1,871.90 \pm 202.00^{\mathrm{ab}}$ \\
\hline $\mathrm{Mg}, \mathrm{mg} / \mathrm{L}$ & $163.69 \pm 9.68^{\mathrm{e}}$ & $175.99 \pm 17.86^{\mathrm{d}}$ & $184.39 \pm 9.82^{\mathrm{c}}$ & $202.04 \pm 17.14^{\mathrm{b}}$ & $205.79 \pm 16.26^{\mathrm{b}}$ & $214.68 \pm 21.11^{\mathrm{a}}$ \\
\hline $\mathrm{pH}$ & $6.73 \pm 0.12^{\mathrm{ab}}$ & $6.75 \pm 0.06^{\mathrm{ab}}$ & $6.69 \pm 0.06^{\mathrm{cd}}$ & $6.71 \pm 0.10^{\mathrm{bc}}$ & $6.76 \pm 0.07^{\mathrm{a}}$ & $6.68 \pm 0.09^{\mathrm{d}}$ \\
\hline
\end{tabular}

${ }^{\mathrm{a}-\mathrm{f}}$ Means within a row with different superscripts differ $(P \leq 0.05)$.

${ }^{1} \mathrm{LDM}=$ lean $\mathrm{DM} ; \mathrm{TN}=$ total nitrogen $\mathrm{NCN}=$ noncasein nitrogen; casein number $=$ casein to true protein ratio.

fraction reported here are in good concordance with those given by Nájera et al. (2009).

As for fat content, the concentration effect caused by lower milk yields can be observed for the protein content (Sevi et al., 2000), at least in the first 4 mo of the study. Regarding protein composition, little information is available on the effects of nutrition on ruminant milk protein profile. The composition of the protein is almost unaffected by the lactation stage in cows, and the nutrition and management of the animals has very little effect on the proportion of the different nitrogen fractions in ruminants (Walker et al., 2004; Pulina et al., 2006). However, it has been reported that cows grazing pasture had higher casein to whey nitrogen ratio than confined animals fed exclusively indoors (Walker et al., 2004). Leiber et al. (2006) reported that casein number (casein to true protein ratio) increased when cows started to graze compared with cows kept in stalls. They also observed an increase of the casein number with progressing lactation for grazing and nongrazing herds. In the present study, both ratios (casein to whey nitrogen and casein to true protein) oscillated throughout the milking season, reaching the highest values $(P \leq 0.05)$ in May (Table 2$)$.

A close correlation between dietary $\mathrm{CP}$ and milk urea has been reported (Pulina et al., 2006). As the $\mathrm{CP}$ of the diet increases, nitrogen conversion efficiency is worse and the excess is lost as NPN (Cannas et al., 1998). Immature pastures are characterized by high $\mathrm{CP}$ content, and a clear influence of increasing grass maturity toward lower milk urea levels has been found (Leiber et al., 2006). This could explain the higher NPN concentrations in April and May and the decreasing trend in later months because urea is the major component of this nitrogen fraction (Park et al., 2007) (Table 2).

Total calcium content tended to increase throughout the milking season. The lowest $(P \leq 0.05)$ concentration was found in February and the highest $(P \leq 0.05)$ in
June (from 1,692.75 to $1,971.08 \mathrm{mg} / \mathrm{L} ;+16.44 \%$; Table 2). Calcium contents reported here were slightly higher than those from a previous work (Nájera et al., 2009) but were around the expected value for ewe milk (Park et al., 2007). Few authors reported a calcium content increase during grazing periods compared with confined feeding periods (Martin and Coulon, 1995; Nájera et al., 2009). However, the response of the concentration of this mineral to nutritional manipulation is very limited (Knowles et al., 2006). Magnesium concentration increased $(P \leq 0.05)$ progressively throughout the milk production period (from 163.69 to $214.68 \mathrm{mg} / \mathrm{L}$; $+31.15 \%$; Table 2). References to the effect of lactation stage or pasture feeding on the magnesium levels were not found in the literature.

Values of $\mathrm{pH}$ fluctuated throughout the season but, although statistical differences were found, the oscillation was negligible, 0.08 being the highest difference among months (Table 2). Macheboeuf et al. (1993) observed a 0.02 increase in milk $\mathrm{pH}$ as a result of turning out to pasture, but that observation was not confirmed.

\section{Coagulation Parameters and Curd Texture}

Significant differences $(P \leq 0.05)$ were found for each rennet coagulation parameter and curd texture measurement because of season and flock factors. The interaction term season $\times$ flock was also significant $(P$ $\leq 0.05)$ for each variable.

Rennet coagulation time underwent a gradual increase $(P \leq 0.05)$ from April to July. Milk samples coagulated about 3 min earlier in the first 3 mo of the experiment than in July (Table 3). Different authors have reported different coagulation time as lactation stage progressed. Some authors reported shorter coagulation times (Joudu et al., 2008), other researchers found nonsignificant differences (Nájera et al., 2009), and few authors measured longer coagulation times (Pellegrini et al., 1994). These contradictory results 
Table 3. Rennet coagulation and curd texture parameters (average values $\pm \mathrm{SD}$ ) of the commercial flocks $(\mathrm{n}=11)$ throughout the milk production season

\begin{tabular}{|c|c|c|c|c|c|c|}
\hline Item $^{1}$ & February & March & April & May & June & July \\
\hline $\mathrm{CoF}, \% \mathrm{RET}^{-1}$ & $0.19 \pm 0.03^{\mathrm{c}}$ & $0.18 \pm 0.03^{\mathrm{d}}$ & $0.18 \pm 0.03^{\mathrm{d}}$ & $0.19 \pm 0.02^{\mathrm{bc}}$ & $0.19 \pm 0.04^{\mathrm{b}}$ & $0.21 \pm 0.03^{\mathrm{a}}$ \\
\hline $\mathrm{CuF}, \% \mathrm{RET}^{-1}$ & $0.21 \pm 0.02^{\mathrm{f}}$ & $0.23 \pm 0.01^{\mathrm{e}}$ & $0.24 \pm 0.01^{\mathrm{d}}$ & $0.27 \pm 0.02^{\mathrm{c}}$ & $0.28 \pm 0.02^{\mathrm{b}}$ & $0.29 \pm 0.02^{\mathrm{a}}$ \\
\hline $\mathrm{CRC}, \mathrm{g}$ & $98.86 \pm 26.86^{\mathrm{c}}$ & $107.79 \pm 11.39^{\mathrm{b}}$ & $111.73 \pm 8.35^{\mathrm{a}}$ & $115.45 \pm 12.29^{\mathrm{a}}$ & $115.28 \pm 8.99^{\mathrm{a}}$ & $113.00 \pm 15.11^{\mathrm{a}}$ \\
\hline
\end{tabular}

${ }^{\mathrm{a}-\mathrm{f}}$ Means within a row with different superscripts differ $(P \leq 0.05)$.

${ }^{1} \mathrm{RCT}=$ rennet coagulation time; $\mathrm{CoF}=$ coagulum firmness; $\mathrm{CuF}=$ curd firmness; $\mathrm{GFR}=$ gel firming rate; CRC $=$ curd resistance to compression; $\% \mathrm{RET}^{-1}=$ inverse of the relative transmission; \% RET $=$ relative transmission.

may have arisen from differences in the methodology used and differences in milk $\mathrm{pH}$ because it is a factor of paramount importance on the rennet coagulation time (Bencini, 2002).

Gel firming rate decreased $(P \leq 0.05)$ from month to month, its value in July being about half of that in February (Table 3). This meant that curds needed more time to achieve the same firmness increment as milking season progressed. Despite the lower gel firming rate, curd firmness increased $(P \leq 0.05)$ gradually with season because the slower rate of coagulation prevailed over the decrease of the gel firming rate as milk production period advanced. Lower gel firming rate and higher curd firmness have been previously reported for late-lactation milks compared with early-lactation milks (Pellegrini et al., 1994; Nájera et al., 2009). Accordingly, curd resistance to compression increased ( $P$ $\leq 0.05)$ progressively until April, but then it reached a plateau that lasted until the end of the milk production period (Table 3).

\section{Relationship Between Milk Composition and Coagulation Properties Throughout the Season}

The transition from indoor feeding to pasture-based diets induced marked changes in most compositional and technological parameters of the milk. Indeed, the largest differences were observed between the milks of April and May, after sheep were allowed to graze for 1 mo (Table 1). This was true for fat, protein (mainly caseins that accounted for $84 \%$ of total protein), magnesium, rennet coagulation time, gel firming rate, and curd firmness (Tables 2 and 3). Some links between compositional and technological parameters and feeding type have been discussed above, but for the sake of a better understanding of the relationships between milk composition and milk coagulation parameters throughout the milking season, PCA was carried out. Four PC were extracted, which explained $73.35 \%$ of total variance (Table 4 ).

Casein and protein contents were highly correlated to PC1 (factor loadings higher than 0.83) together with the lean DM content (factor loading of 0.67) and the curd resistance to compression (factor loading of 0.83; Table 4). The study conducted by Malacarne et al. (2006) also showed that milk with higher casein content provided curds with higher resistance to compression. This rheological parameter gives a measure of the texture of the curd and is logically linked to the proteins, especially caseins, because they are responsible for forming the structural network of the curd (Lucey et al., 2003). Curd firmness, as a measure of the rearrangement of the internal bonds of the gel, is also correlated to the curd resistance to compression. It showed a positive factor loading (0.57) with PC1. To a lesser extent, rennet coagulation time also correlated positively to PC1 (factor loading 0.53 ). In this sense, other authors have reported longer coagulation times in milk samples with high TS content (Clark and Sherbon, 2000).

Curd firmness and the compositional variables fat, magnesium, and calcium contents had positive loadings $(\geq 0.71)$ with $\mathrm{PC} 2$, whereas gel firming rate correlated negatively $(-0.72)$ with this component. Protein con-

Table 4. Rotated factor loadings for the principal component (PC) analysis applied to compositional and technological variables of milks from commercial flocks throughout the milk production season ${ }^{1,2}$

\begin{tabular}{lcrrr}
\hline Item $^{3}$ & PC 1 & PC 2 & PC 3 & PC 4 \\
\hline CRC & 0.834 & & & \\
Casein & 0.829 & & & \\
Protein & 0.817 & 0.403 & & \\
LDM & 0.670 & 0.813 & & \\
Mg & & 0.784 & & \\
Ca & & -0.718 & & \\
GFR & & 0.714 & & \\
Fat & 0.566 & 0.710 & 0.835 & \\
CuF & & & -0.644 & \\
NPN & & & & 0.799 \\
CoF & 0.532 & & & 0.587 \\
pH & & & \\
RCT & & & \\
\hline
\end{tabular}

${ }^{1}$ Factor loadings lower than 0.400 are set to 0 .

${ }^{2}$ Percentage of explained variance: PC $1=27.45 \%$; PC $2=24.88 \%$; PC $3=10.65 \%$, PC $4=10.36 \%$.

${ }^{3} \mathrm{CRC}=$ curd resistance to compression $; \mathrm{LDM}=$ lean DM; GFR $=$ gel firming rate; $\mathrm{CuF}=$ curd firmness; $\mathrm{CoF}=$ coagulum firmness; $\mathrm{RCT}=$ rennet coagulation time. 
tent also correlated positively to this component but with lower factor loading (0.40). It has been reported that milk with higher fat and protein contents formed firmer curds (Clark and Sherbon, 2000). Storry et al. (1983) also found a positive correlation between curd firmness and milk fat, casein, magnesium, and calcium contents.

As lactation progressed and diet changed to include ever higher levels of fresh pasture and lower amounts of concentrate and forage, the milk composition was richer in lean DM, fat, protein, and mineral contents. The seasonality was reflected in PC1 and PC2. During the first part of the study, when the indoor diet was predominant, there was a similar evolution of all the compositional variables. In the last months, when outdoor grazing prevailed, proteins and lean DM stabilized whereas fat and magnesium contents increased. Calcium content had a staggered evolution, which differed from the other variables, but it was grouped in $\mathrm{PC} 2$ because of its correlation with curd firmness. Thus, PC1 was called indoor feeding factor, which was mainly correlated to proteins and curd resistance to compression, and PC2 was named outdoor grazing factor, which mainly correlated to fat, minerals, and curd firmness.

Coagulum firmness and NPN content, which consists mainly of urea, creatin, and free AA (Park et al., 2007), showed high factor loadings with PC3 $(>|0.64|)$. The correlation between those 2 variables was negative (Table 4). This correlation has not been previously reported by other authors, but it does make sense because few authors have reported that urea could alter the gel forming process (Guinot, 1992; Verdier-Metz et al., 2001). Principal component 3 was defined as coagulum forming factor.

Rennet coagulation time and $\mathrm{pH}$ showed positive factor loadings with PC4 (>0.59; Table 4$)$. The same correlation was observed by Nájera et al. (2009). Other authors reported that lower $\mathrm{pH}$ positively influenced renneting properties by enhancing the activity of chymosin and modifying the conformation and structure of casein micelles (O'Brien et al., 2006). Low pH provokes solubilization of calcium and positively affects the aggregation rate of $\kappa-\mathrm{CN}$, increasing the coagulation velocity (Malacarne et al., 2006). Principal component 4 was defined as renneting time factor.

A discriminant analysis was applied to observe the distribution of the samples and go further in the study of the influence of the season associated with the feeding changes in the composition and coagulation properties of the ewe milk. Milk samples were grouped according to feeding regimen. The indoor group comprised the milk samples from the flocks that did not have access to pasture (February), the transition group comprised the milk samples from the beginning of the grazing period when sheep had been grazing up to 1 mo (March and April), and the outdoor group comprised the milk samples from the flocks that were predominantly grazing and had little supplementation of concentrate and forage (May, June, and July). Figure 1 shows the distribution of milk samples according to the feeding type in the coordinate system defined by the 2 canonical discriminant functions. As can be observed, the indoor and outdoor groups were correctly separated, whereas $21.4 \%$ of the transition group samples were classified as samples of the indoor group and $9.5 \%$ as samples of the outdoor group. The analysis established 3 variables capable of discriminating among the 3 feeding regimens: curd firmness, fat, and magnesium content. Function 1 explained $99.4 \%$ of total variance and the 3 discriminant variables contributed similarly to this canonical function. These particular variables were highly correlated to outdoor grazing factor (PC2) of the PCA, which meant that the pasture-related variables were the most relevant for discriminating ewe raw milk samples throughout the season.

\section{CONCLUSIONS}

A marked influence of the season associated with the feeding management under part-time grazing was ob-

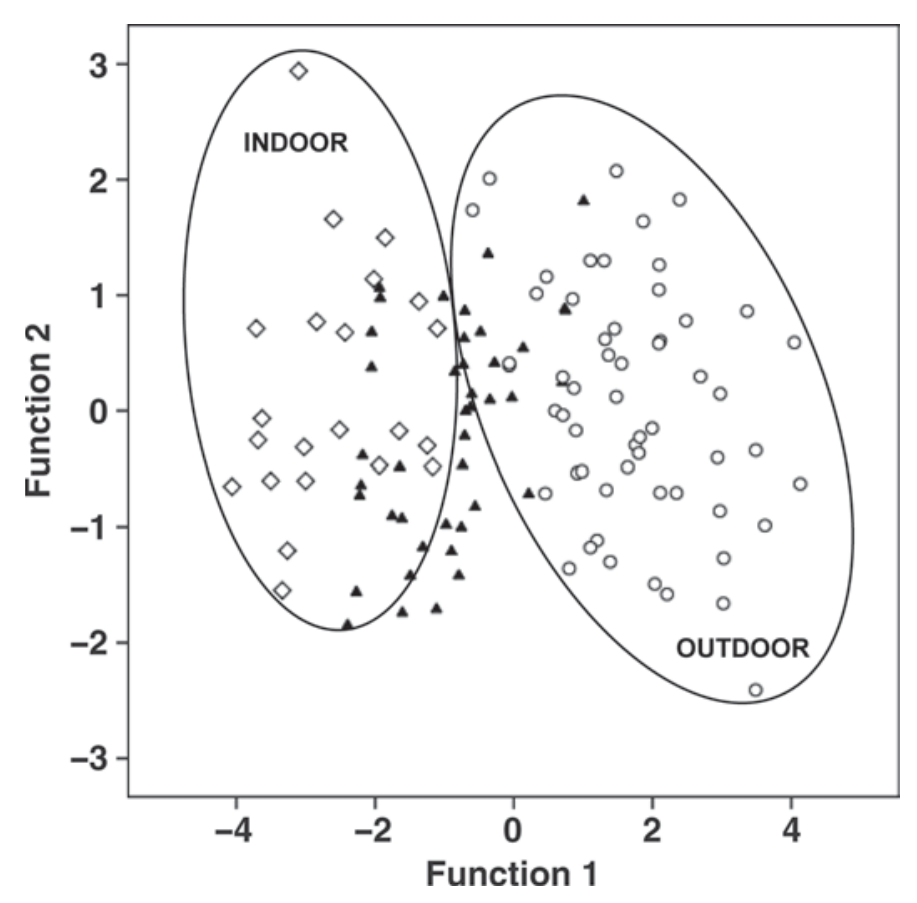

Figure 1. Ewe milk sample distribution according to the feeding regimen in the 2-dimensional coordinate system defined by canonical discriminant functions $(\diamond=$ indoor feeding; $\boldsymbol{\Delta}=$ transition feeding; $\bigcirc$ $=$ outdoor feeding). 
served on the composition and technological quality of ewe raw milk. Protein, casein, and lean DM content as well as curd resistance to compression increased during the first period of the study and stabilized during the outdoor grazing period. Fat and magnesium, together with curd firmness, underwent a progressive increase throughout the whole milking period. These 3 variables were capable of discriminating between milks from the indoor feeding period (February) and milks from the outdoor grazing period (May-July). They reflected the evolution of the composition and coagulation properties during the last months of the study when pasture was the predominant feed in the diet of the flocks. The good technological quality of the milk when sheep are fed pasture is an incentive to encourage sheepherders to design their feeding management to take advantage of the natural resources as much as they can, giving continuity to this sustainable production system.

\section{ACKNOWLEDGMENTS}

This work was supported by grants from the Universidad del País Vasco/Euskal Herriko Unibertsitatea (Leioa, Spain; UNESCO Cathedra/05102) and the INIA (Instituto Nacional de Investigación y Tecnología Agraria y Alimentaria; RTA 2006-00100-C02-02). E. Abilleira acknowledges a predoctoral fellowship from the Basque Government.

\section{REFERENCES}

Barron, L. J. R., E. Fernández de Labastida, S. Perea, F. Chávarri, C. de Vega, M. S. Vicente, M. I. Torres, A. I. Nájera, M. Virto, A. Santisteban, F. J. Pérez-Elortondo, M. Albisu, J. Salmerón, C Mendia, P. Torre, F. C. Ibañez, and M. de Renobales. 2001. Seasonal changes in the composition of bulk raw ewe's milk used for Idiazabal cheese manufacture. Int. Dairy J. 11:771-778.

Bencini, R. 2002. Factors affecting the clotting properties of sheep milk. J. Sci. Food Agric. 82:705-712.

Cannas, A., A. Pes, R. Mancuso, B. Vodret, and A. Nudda. 1998. Effect of dietary energy and protein concentration on the concentration of milk urea nitrogen in dairy ewes. J. Dairy Sci. 81:499-508.

Clark, S., and J. W. Sherbon. 2000. Alpha s1-casein, milk composition and coagulation properties of goat milk. Small. Rumin. Res. 38:123-134.

De la Fuente, M. A., B. Carazo, and M. Juárez. 1997. Determination of major minerals in dairy products digested in closed vessels using microwave heating. J. Dairy Sci. 80:806-811.

García-Rodríguez, A., and L. M. Oregui. 2004. Effect of time spent on pasture and protein content of the concentrate on milk yields and body reserves. Pages 662-664 in Proc. 20th Gen. Meet. Eur. Grassl. Fed., Luzern, Switzerland. Eur. Grassl. Fed., Zurich, Switzerland.

Guinot, T. P. 1992. Technological and microbiological consequences related to urea addition to milk. Aust. J. Dairy Technol. 47:5859.

IDF. 1981. Milk determination of fat. Standard 105. International Dairy Federation, Brussels, Belgium.

IDF. 1987. Milk, cream \& evaporated milk. Determination of solids content. Standard 021B. International Dairy Federation, Brussels, Belgium.
IDF. 1991. Enumeration of microorganisms. Standard 100B. International Dairy Federation, Brussels, Belgium.

IDF. 1995. Enumeration of somatic cells. Standard 148A. International Dairy Federation, Brussels, Belgium.

Jaeggi, J. J., W. L. Wendorff, J. Romero, Y. M. Berger, and M. E. Johnson. 2005. Impact of seasonal changes in ovine milk composition and yield of a hard-pressed cheese. J. Dairy Sci. 88:13581363.

Joudu, I., M. Henno, T. Kaart, T. Pussa, and O. Kart. 2008. The effect of milk protein contents on the rennet coagulation properties of milk from individual dairy cows. Int. Dairy J. 18:964-967.

Knowles, S. O., N. D. Grace, T. W. Knight, W. C. McNabb, and J. Lee. 2006. Reasons and means for manipulating the micronutrient composition of milk from grazing dairy cattle. Anim. Feed Sci. Technol. 131:154-167.

Leiber, F., M. Kreuzer, H. Leuenberger, and H. R. Wettstein. 2006 Contribution of diet type and pasture conditions to the influence of high altitude grazing on intake, performance and composition and renneting properties of the milk of cows. Anim. Res. 55:37-53.

Lucey, J. A., M. E. Johnson, and D. S. Horne. 2003. Invited review: Perspectives on the basis of the rheology and texture properties of cheese. J. Dairy Sci. 86:2715-2743.

Macheboeuf, D., J. B. Coulon, and P. Dhour. 1993. Effect of breed, protein genetic-variants and feeding on cows milk coagulation properties. J. Dairy Res. 60:43-54.

Malacarne, M., A. Summer, E. Fossa, P. Formaggioni, P. Franceschi, M. Pecorari, and P. Mariani. 2006. Composition, coagulation properties and Parmigiano-Reggiano cheese yield of Italian Brown and Italian Friesian herd milks. J. Dairy Res. 73:171-177.

Mandaluniz, N., A. Aldezabal, and L. M. Oregui. 2009. Atlantic mountain grassland-heathlands: Structure and feeding value. Span. J. Agric. Res. 7:129-136.

Martin, B., and J. B. Coulon. 1995. Facteurs de production du lait et caractéristiques des fromages. I. Influence des facteurs de production sur l'aptitude à la coagulation des laits de troupeaux. Lait 75:61-80.

Morand-Fehr, P., V. Fedele, M. Decandia, and Y. Le Frileux. 2007. Influence of farming and feeding systems on composition and quality of goat and sheep milk. Small Rumin. Res. 68:20-34.

Nájera, A. I., L. J. R. Barron, P. Ribeiro, F. Pèlissier, E. Abilleira, F. J. Pérez-Elortondo, M. Albisu, J. Salmerón, J. C. Ruiz de Gordoa, M. Virto, L. Oregui, R. Ruiz, and M. de Renobales. 2009. Seasonal changes in the technological and compositional quality of ewe's raw miles from commercial flocks under part-time grazing. J. Dairy Res. 76:301-307.

Nájera, A. I., M. de Renobales, and L. J. R. Barron. 2003. Effects of $\mathrm{pH}$, temperature, $\mathrm{CaCl}_{2}$ and enzyme concentration on the rennet-clotting properties of milk: Multifactorial study. Food Chem. $80: 345-352$.

O'Brien, B., T. P. Guinee, A. Kelly, and P. Joyce. 2006. Processability of late-lactation milk from a spring-calved dairy herd. Aust. J. Dairy Technol. 61:3-7.

Park, Y. W., M. Juárez, M. Ramos, and G. F. W. Haenlein. 2007. Physico-chemical characteristics of goat and sheep milk. Small Rumin. Res. 68:88-113.

Pellegrini, O., F. Remeuf, and M. Rivemale. 1994. Évolution des caractéristiques physico-chimiques et des paramètres de coagulation du lait de brebis collecté dans la région de Roquefort. Lait 74:425-442.

Perojo, A., A. Garcia-Rodriguez, J. Arranz, and L. Oregui. 2005. Effects of time spent on pasture on milk yield, body reserves, herbage intake and grazing behaviour. Options Méditerranéennes A $67: 275-279$.

Pulina, G., A. Nudda, G. Battacone, and A. Cannas. 2006. Effects of nutrition on the contents of fat, protein, somatic cells, aromatic compounds, and undesirable substances in sheep milk. Anim. Feed Sci. Technol. 131:255-291.

Rowland, S. J. 1938. The determination of the nitrogen distribution in milk. J. Dairy Sci. 9:42-46. 
Sevi, A., L. Taibi, M. Albenzio, A. Muscio, and G. Annicchiarico. 2000. Effect of parity on milk yield, composition, somatic cell count, renneting parameters and bacteria counts of Comisana ewes. Small Rumin. Res. 37:99-107.

Soryal, K. A., S. S. Zeng, B. R. Min, S. P. Hart, and F. A. Beyene. 2004. Effect of feeding systems on composition of goat milk and yield of Domiati cheese. Small Rumin. Res. 54:121-129.

Storry, J. E., A. S. Grandison, D. Millard, A. J. Owen, and G. D. Ford. 1983. Chemical composition and coagulating properties of renneted milks from different breeds and species of ruminant. J. Dairy Res. 50:215-229.

Verdier-Metz, I., J. B. Coulon, and P. Pradel. 2001. Relationship between milk fat and protein contents and cheese yield. Anim. Res. 50:365-371.

Walker, G. P., F. R. Dunshea, and P. T. Doyle. 2004. Effects of nutrition and management on the production and composition of milk fat and protein: A review. Aust. J. Agric. Res. 55:1009-1028. 